\title{
浅析提高建筑工程质量管理的对策
}

\author{
俞建波 ${ }^{1}$ 翁成 ${ }^{2}$ \\ 1 桐庐利越建设有限公司 2 桐庐大奇山郡置业有限公司 \\ DOI:10.32629/btr.v2i3.1903
}

[摘 要] 建筑企业是国民经济重要产业, 建筑工程质量是关系到社会的公共利益和公共安全, 然而要控制工程质量就必须对 前期施工阶段质量进行有效控制,本文针对影响建筑工程质量的因素进行分析,并提出了相应的对策。

[关键词] 建筑工程; 质量管理; 对策

建筑产品质量的好与坏都是与人们日常生活紧密联系 在一起的, 那么建筑企业在施工的时候就应该将施工质量看 成是企业的生命, 在建筑工程施工过程当中应将质量的管理 作为企业管理的重中之重, 在管理人员的思想中对于工程质 量的重要性要有清醒的认识, 在施工的过程只中要从各个环 节全面落实质量责任, 保证建设工程质量完全达标。

\section{1 搞好建筑工程质量的重大意义}

建筑工程质量的好坏, 与国家长远利益、国民经济发展、 实现四个现代化息息相关。质量好的工程, 可以增加固定资 产的耐久性, 减少固定资产的使用维修费, 为人民的生产和 生活提供良好的条件。而质量差的工程, 不仅要进行返工, 造成人力、物力上的巨大浪费, 而且会延误建设速度, 影响投 资效益的迅速发挥, 还会造成生产上的长期不合理, 或者影 响产品的正常生产, 严重的更会造成人民生命财产的重大损 失。当中有关技术活动偏离规定要求的现象, 使其恢复正常, 从而达到控制的目的。使影响产品质量的技术因素、管理因 素及人的因素等始终处于受控的状态下。故此, 我们必须 高标准、严要求, 切实搞好工程质量, 为国家、用户提供一流 的建设工程。

\section{2 建筑工程质量管理中存在的主要问题}

从建筑工程项目的整体管理角度而言, 工程管理工作主 要是指: 从建筑工程项目立项开始, 经过招投标、整体规划、 设计、工程造价、施工、竣工验收等项目的综合管理, 最终 保证建筑工程项目实现 “质量良好、成本低而效益高” 的目 标。目前, 我国普遍缺乏系统在工程管理、专业、深入的理 论研究和讨论, 导致存在的问题在中国施工项目管理、滥用, 开拓更多的客观现实, 必须有针对性的改进与完善。

\section{1 管理体制不健全}

目前, 我国在建设管理、管理体制中的关键问题是体制 不健全。完善管理体系的建设工程项目管理部门和机构建立 的全部功能, 并且根据实际需求, 分别得到不同数量的人员 配备来满足特殊的工程项目管理工作需求。不过大多数我国 建筑工程为了节约成本, 并极大地降低了工程管理部门, 员 工的数量, 这将导致不完整的管理和员工, 甚至管理者要身 体的数量和水平。缺乏健全的管理体制, 建筑工程的管理工 作也就无从谈起了。

\section{2 缺乏明确的质量监管核心与机制}

目前, 国内建筑工程管理工作中的施工质量监督与控制 工作多是由施工单位、监理单位、质检机构共同承担和完成, 各单位之间没有隶属关系, 相互之间的合作与交流以沟通为 主要方式, 这就导致建筑工程施工质量控制工作缺乏明确的 监管核心, 更难以谈到监管机制的构建与发展了。施工单位 在施工质量控制工作中, 更多的是站在经济收益与社会利益 的角度上来考虑问题; 监理单位是独立于建设单位、施工单 位的第三方, 具有监理工程质量、进度等职责, 但是由于国内 工程监理行业尚处于起步阶段, 监理单位难以挑起施工质量 监管核心的重任; 质检机构是隶属于国家的工程㫌工质量鉴 定与检测机构, 其属于科研技术研究机构, 不具备相应的执 法权, 也无法成为施工质量监管的核心。

\section{3 安全管理意识淡薄}

在我国建筑工程管理工作中, 管理的重点多集中于施工 工艺、技术、进度、质量、造价等方面, 而对于工程安全的 管理则处于相对被忽视的地位。我国施工队伍主要由农民工 组成, 他们普遍没有经过专业的培训和教育, 导致其安全技 术和意识难以满足实际需求。

\section{3 提高我国建筑工程质量管理的对策}

3.1 强化施工项目全员的素质

施工项目中的工作人员是整个工程项目的主体, 是整个 工程产品的直接创造者, 施工人员的技术水平和整体综合素 质对于施工产品的质量都有着一定的影响。施工技术人员和 管理人员都认真做到将工程质量和企业发展命运紧密的联 系在一起, 进一步将整体施工质量加以提高, 然而对于工作 人员的施工水平和整体综合素质都是在现代建设施工新的 环境下必须面临新课题。对工程质量进行有效的控制和确保 高水准的工程质量, 都是需要有效的工程质量控制进行确保, 这是我们施工人员在长时间的工程建设工作中总结出来的。

\section{2 健全质量体系}

建筑企业想要将工程质量全面的做好, 就需要加强建立 完善的质量体系, 质量体系实现工程质量的组织和程序以及 资源的保障, 对于施工企业来说, 质量体系是客观存在的, 主 要是问是企业质量体系是否科学合理和及健全实用, 与国际 质量管理和质量保证是否有效的相互接轨。首先我们需要系 
统的建立思想和健全文件化的质量体系, 对工程质量形成的 全过程和所有的质量活动进行统计分析, 全面控制并形成文 件化; 其次, 还需要注重质量体系的可操作性, 传统的质量管 理体系虽然不能够使用现代新的管理模式, 但是我们也不能 够全部将其推翻, 有些精华管理体系我们还是需要借鉴和加 以利用, 对照新的规范标准我们将传统可利用部分进行完善 和补充; 最后, 还需要注重持续有效的运行, 保证质量体系持 续有效和良心循环。

\section{3 控制好质量管理的全过程}

建筑企业对于每一个项目都要质量计划和质量保证以 及质量控制, 定期进行检查, 并将质量管理和检查报告递交 给上级审核, 对于施工现场的质量管理我们尤为需要重视, 具体可以做以下说明: (1)要做好事先计划; (2)加强施工控制; (3)重视时候检查。笔者根据多年实践经验, 加强施工现场的 监督管理是提高建筑工程质量的关键, 针对施工过程中的每 一个细节都需要做到完美衔接, 不能够出现任何一个错误。

3.4 加强验收工作

当建筑工程施工结束后, 需要对整个工程的质量进行验 收, 这是不可缺少的环节。工程验收包括了分部、分项工程 的验收以及单位工程的验收。对于工程质量进行验收时, 其 重点在于对建筑工程中的各个组成构件性能进行验收, 可要 求专业的技术人员对建筑性能进行检测, 保障建筑程参数指 标达到标准后再正式投入运用。对出现不符合标准的建筑物 需及时通知施工单位安排处理, 结合施工图纸详细分析原因, 再从根本上处理好建筑质量问题。

3.5 积极探索新科技, 提高工程管控水平

技术的重要性不言而喻, 所以施工的质量控制同样离不 开技术, 只有通过技术的改进, 才能实现产品和施工工艺的 更新换代。所以看重工程质量就要重视新技术、新工艺的先
进性、适用性。更要明确在施工的过程中利用符合技术要求 的一系列流程, 质量要求, 操作的规范, 与此同时设立严格的 考核制度, 不断地改进和提高施工技术和工艺水平, 确保工 程质量。

总而言之, 建筑工程质量管控是一个全面的系统的工 程, 所以想要提高工程质量管控水平, 就一定要做好准备施 工前的所有准备工作, 还有施工过程的监管和后期的竣工 验收工作, 只有把每一个过程和工艺都完善的同时,在积极 的配备先进的而技术, 才能真正提高质量管控的水平,保证 工程质量。

\section{4 结束语}

综上所述, 建筑工程的施工质量好坏直接的关系到人 民的生命财产以及经济利益, 而如何才能够更好的搞好质 量管理工作则是工程施工的关键, 所以相关企业、单位必须 形成工程质量优先的共识, 从而充分的发挥各自的优势, 进 一步密切配合, 只有这样, 才能够使建筑工程质量再上一个 新台阶。

\section{[参考文献]}

[1]陈丽萍.建筑工程施工质量控制方法及对策初探[J]. 科技广场,2009(08):25-26.

[2]黄东兴,范雪华. 建筑工程施工质量过程管理与控制 [J].中国建设信息,2010(09):35+42.

[3]苏现锋.建筑施工质量管理策略探究 [J].中国新技术 新产品,2010(03):57.

[4]贺德国.建筑工程管理中的成本控制 [J].科技与企 业,2012(3):53.

[5]周雪.论有效提高建筑工程管理技术的措施[J]. 黑龙 江科技信息,2012(4):41-42. 